\title{
Analysis of Cytokines in the Aqueous Humor During Intravitreal Treatment With Ranibizumab in Diabetic Macular Edema
}

Luiz Guilherme Azevedo Freitas ( $\square$ luizgfreitas@gmail.com )

Santa Luzia Eye Hospital / Santa Luzia Foundation - Recife (PE)

David Leonardo Cruvinel Isaac

Federal University of Goiás - UFG - Goiânia (GO)

Murilo Batista Abud

Federal University of Goiás - UFG - Goiânia (GO)

Alexandre Dantas Soares Quintas Segundo

Santa Luzia Eye Hospital / Santa Luzia Foundation - Recife (PE)

Mariana Larissa Alvino Barros

Santa Luzia Eye Hospital / Santa Luzia Foundation - Recife (PE)

Gabriela Caroline Monteiro Albuquerque

Santa Luzia Eye Hospital / Santa Luzia Foundation - Recife (PE)

Bruna Dantas Aires Guimarães

Santa Luzia Eye Hospital / Santa Luzia Foundation - Recife (PE)

Clarice Neuenschwander Lins Morais

Oswaldo Cruz Foundation

Marcos Pereira Ávila

Federal University of Goiás - UFG - Goiânia (GO)

\section{Research Article}

Keywords: Angiofluoresceinography, Cytokines, Ischemia, Inhibitors of Angiogenesis, Diabetic

Retinopathy

Posted Date: August 23rd, 2021

DOI: https://doi.org/10.21203/rs.3.rs-803720/v1

License: (1) (1) This work is licensed under a Creative Commons Attribution 4.0 International License.

Read Full License 
Version of Record: A version of this preprint was published at Scientific Reports on December 1st, 2021. See the published version at https://doi.org/10.1038/s41598-021-03433-2. 


\section{Abstract}

Purpose: This study aimed to analyze the concentrations, in aqueous humor, of VEGF, b-FGF, TNF, and interleukins $1,6,8,10$, and 12 in patients with diabetic macular edema, with and without peripheral retinal ischemia, and to analyze the variation of the levels of these molecules, during the treatment with ranibizumab.

Methods: A therapeutic, prospective, randomized interventional study was carried out. Twenty-four eyes from 24 patients were studied, divided into 3 groups. Group 1, (9 eyes), patients with EMD without peripheral ischemia. Group 2 (10 eyes), patients with EMD with peripheral ischemia. Group 3, (5 eyes), control group, formed by patients without systemic and/or eye diseases. Patients in groups 1 and 2 were treated with 3 intravitreal injections of $2 \mathrm{mg} / 0.05 \mathrm{ml}$ of ranibizumab, with intervals of approximately 30 days. Before performing the injections, the aqueous humor was collected. In the control group, the material was collected before the facectomy procedure.

Results: During treatment, the medians of IL-6 concentrations showed a statistically significant increase, in group 1 and group 2, there was a slight decrease, not statistically significant. Interleukin 8 showed statistically significant variations in groups 1 and 2, at the end of treatment. TNF, IL-1, IL-10, and IL-12 had their concentrations practically unchanged, in both groups. VEGF showed a statistically significant reduction in groups 1 and 2 at the end of the study. B-FGF was not detected in most of the studied patients, and in those that were found, they did not present statistically significant numbers.

Conclusion: There were statistically significant variations in the increase of their median levels in interleukin 6, in the group without ischemia and a decrease in VEGF in both groups. The cytokines TNF, IL1, IL-10, and IL-12 did not show statistically significant variations.

\section{Key Messages}

- Diabetic retinopathy is one of the main causes of vision loss in the world and the macular edema is considered the main responsible for visual impairment in patients with this disease.

- Many cytokines such as VEGF, b-FGF, TNF and interleukins 1, 6, 8, 10 and 12 can participate in the formation and maintenance of diabetic macular edema.

- Intravitreal antiangiogenic drugs may interfere with the variation of these cytokines over the course of treatment.

- Interleukin 6 and VEGF were the ones with statistically significant participations during the treatment of diabetic macular edema with an antiangiogenic drug, ranibizumab.

\section{Introduction}

Diabetic retinopathy (DR) is one of the main causes of vision loss in the world ${ }^{1}$. 
Macular edema (ME) is considered the main responsible for visual impairment in patients with diabetic retinopathy, which can appear in all stages of the disease, affecting approximately $30 \%$ of diabetic patients, with more than 20 years of the disease $\mathrm{e}^{2,3,4,5}$.

Tests such as optical coherence tomography (OCT) and fluorescein angiography (FA) are performed for diagnosis and monitoring of patients with $\mathrm{DR}^{6}$.

Fluorescein angiography is essential for the ability to acquire information about the stages of the disease $\mathrm{e}^{7,8}$. New devices called wide-angle fluorescein angiography can capture images with angles between $55^{\circ}$ and $200^{\circ}$. This new technology has aroused the interest in analyzing the retinal periphery

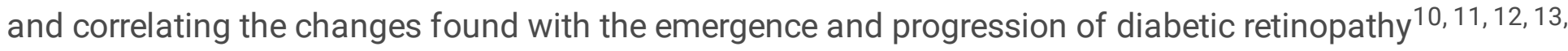
14 .

We believe that regions of poor perfusion stimulate the production of vascular endothelial growth factor (VEGF) and that their high levels, in the vitreous, induce the formation of $\mathrm{ME}^{14,15,16,17}$.

It is not only VEGF that is increased in patients with diabetic retinopathy. Cytokines such as interleukins, TNF, and b-FGF are also altered in this disease $18,19,20,21,22,23,24$.

We performed an unprecedented study in which we recruited patients with diabetic macular edema, with and without peripheral retinal ischemia, for analysis and comparison of the levels of concentrations, of the molecules Interleukin 1, 6, 8, 10, and 12, TNF, VFGF, and b- FGF, during treatment with intravitreal injections of ranibizumab.

\section{Methods}

All methods were performed according to relevant guidelines.

The consent form was signed by all research participants as well as by their legal guardian.

\section{Study population and design}

Therapeutic, prospective, randomized interventional study. The sample consisted of 24 eyes, 24 patients, divided into 3 groups. Group 1, (9 eyes), with DME without peripheral retinal ischemia. Group 2, (10 eyes), with DME, with peripheral retinal ischemia. Group 3 was (5 eyes) a control group, formed by a patient without systemic and eye diseases.

Patients in groups 1 and 2 underwent 3 intravitreal injections of ranibizumab, with intervals of approximately 30 days. Before each procedure, we collected samples of the aqueous humor (Figure 1). In group 3, samples were collected on the day they underwent cataract surgery.

We performed optical coherence tomography in the Heidelberg Spectralis ${ }^{\circledR}$ HRA + OCT for the diagnosis of edema and angiography with a non-contact lens, in the Ultra-Widefield Spectralis $\AA$ module, with $102^{\circ}$ 
angle, to detect the presence of peripheral retinal ischemia.

The study was approved by the Ethics Committee in the Medical Research Ethics Council of Hospital Agamenon Magalhães, Recife, Pernambuco.

\section{Analysis of cytokines}

For Interleukins 1, 6, 8, 10, 12, and TNF, the Human Inflammatory Cytokine (BD) kit was used and for human VEGF and bFGF molecules, the dosage was through CBA FLEX SET, both kits from the manufacturer BD Medical.

\section{Evaluation of results and statistical analysis}

In this study, data were previously evaluated for parametric or non-parametric approaches. Thus, the variables involved in the study were tested for their distribution of normality and homogeneity using the tests by Shapiro Wilk and Bartlett respectively.

The significance level of $5 \%$ was used to confirm the conclusions. We used the software $R$ ( $R$ DEVELOPMENT CORE TEAM, 2016) to evaluate the results of the study.

\section{Inclusion criteria}

People with diabetic macular edema diagnosed by wide-angle fluorescein angiography exams and optical coherence tomography; age equal to or above 18 years old; without previous treatment with laser photocoagulation antiangiogenic drugs, less than 3 months ago.

\section{Exclusion criteria}

Cataract patients, corneal or vitreous opacities that prevented adequate visualization of the retina; patients with macular edema that was not due to diabetic retinopathy; patients undergoing previous vitreoretinal surgery in the eye to be studied and the patient's refusal to participate in the study.

\section{Performing clinical and complementary examinations}

Patients underwent ophthalmic clinical evaluation. Visual acuity exams were performed with better correction by ETDRS, applanation tonometry, biomicroscopy, and indirect binocular ophthalmoscopy.

The optical coherence tomography and fluorescein angiography examinations were performed using the Heidelberg Spectralis ${ }^{\circledR}$ HRA + OCT. A non-contact lens was used in the Ultra-Widefield Spectralis ${ }^{\circledR}$ module to capture the $102^{\circ}$ wide-field angiographic image.

\section{Collection and analysis of aqueous humor}

Limbar paracentesis was performed with a 30 -gauge needle attached to a $1 \mathrm{ml}$ syringe. Sample volumes ranged between $0.10 \mathrm{ml}$ and $0.3 \mathrm{ml}$. 
We quantified the cytokine levels using the Cytometric Bead Array (CBA) system, following the manufacturer's instructions (BD Biosciences, USA). The cytokines IL-1, IL-6, IL-8, IL-10, IL-12, and TNF were analyzed using the Human Inflammatory Cytokine (BD) kit, and the human VEGF and b-FGF molecules dosed through CBA FLEX SET also from BD.

\section{Results}

\section{Group 1:}

The group has 9 patients ( 4 males and 5 females), aged between 52 and 77 years old ( \pm 9.34 ), with diabetic macular edema without peripheral retinal ischemia, undergoing monthly treatment with ranibizumab.

\section{Visual acuity and macular thickness}

At the end of the research, 8 showed improvement in visual acuity. One patient showed no visual improvement, remaining with the same initial vision (Figure 2).

Upon OCT examination, all patients presented a reduction in central macular thickness upon analysis of the macular thickness map, as illustrated in two patients (Figure $\mathbf{3}$ ).

\section{Clinical examinations and fluorescein angiography}

Upon biomicroscopy examination, one patient was pseudophakic and 08 were phakic. No lens had progressed to cataracts during the study.

At gonioscopy, the presence of neovessels at an angle or iris was not seen before and at the end of the research.

Upon examination of angiography, no patient presented vascular changes of the staining type or retinal neovascularization during the treatment period.

\section{Group 2:}

The group had 10 patients ( 7 males and 3 females), aged between 47 and 68 years ( \pm 7.06$)$, all with DME with peripheral retinal ischemia, undergoing monthly treatment with ranibizumab.

\section{Visual acuity and macular thickness}

At the end of the research, 8 patients showed improvement in visual acuity. Those who did not improve maintained initial visual acuity (Figure 2).

Upon OCT examination, all patients presented a reduction in central macular thickness upon analysis of the macular thickness map, as illustrated in two patients (Figure 4). 


\section{Clinical examinations and fluorescein angiography}

Upon biomicroscopy examination, 9 patients were phakic. No lens had progressed to cataracts during the survey. At gonioscopy, the presence of neovessels at an angle or iris was not seen before and at the end of the research.

At the beginning of the study, on angiography, two patients had retinal neovessels and one of them also had disc neovessels at the beginning of treatment. At the end of the study, both patients presented regression of the new vessels (Figure 5).

\section{Analysis of cytokines in aqueous humor}

Comparison of the medians between the beginning and the end of the treatment, in groups 1 and 2 . In the data of the control group, we used the values at the beginning of the treatment such as the baseline levels (Table 1).

The values in the control group were as follows: IL-1: 0 pg/ml, IL-6: $8.23 \mathrm{pg} / \mathrm{ml}, \mathrm{IL}-8: 4.66 \mathrm{pg} / \mathrm{ml}, \mathrm{IL}-10$ : $5.57 \mathrm{pg} / \mathrm{ml}$, IL-12: $3.4 \mathrm{pg} / \mathrm{ml}$, TNF: $3.8 \mathrm{pg} / \mathrm{ml}$, VFGF: $132.54 \mathrm{pg} / \mathrm{ml}$ ) and b-FGF: $0.00 \mathrm{pg} / \mathrm{ml}$ (Table 1).

In analysis, of the variation of medians of IL-6, during treatment, we observed that, in group 1, it presented a statistically significant increase, at the end of the research in group $1(10.78-26.35 \mathrm{pg} / \mathrm{ml}, \mathrm{p}=0.0148)$.

In group 2, there was a slight decrease in the median of its concentrations, but it was not statistically significant (28.02 - $27.41 \mathrm{pg} / \mathrm{ml}, \mathrm{p}=0.0194)$ (Figure 6).

Regarding IL-8, there were statistically significant variations in groups 1 and 2 . Variation of medians in group 1 , between $13.8 \pm 3.95 \mathrm{pg} / \mathrm{ml}$ and $18.15 \pm 12.65 \mathrm{pg} / \mathrm{ml}(\mathrm{p}=0.0234)$ and, in group 2, between 15.43 $\pm 10.65 \mathrm{pg} / \mathrm{ml}$ and $20.8 \pm 19.73 \mathrm{pg} / \mathrm{ml}(p=0.037)$ (Figure 7).

There was a reduction in the values in the medians of IL-1, which was not statistically significant in both groups. The variations were $1.61 \pm 1.66 \mathrm{pg} / \mathrm{ml}$ and $0.0 \pm 2.53 \mathrm{pg} / \mathrm{ml}, \mathrm{p}=0.4185$ (group 1) and $0.81 \pm 0.85$ $\mathrm{pg} / \mathrm{ml}$ and $0.56 \pm 0.92 \mathrm{pg} / \mathrm{ml}, \mathrm{p}=0.441$ (group 2) (Table 2).

Two interleukins, IL-10 and IL-12 had their concentrations practically unchanged, in both groups. Interleukin 10, in group 1, varied between $5.62 \pm 0.70 \mathrm{pg} / \mathrm{ml}$ and $5.29 \pm 1.17 \mathrm{pg} / \mathrm{ml},(p=1.00)$ and, in group 2, between $5.71 \pm 0.40 \mathrm{pg} / \mathrm{ml}$ and $5.76 \pm 0.297 \mathrm{pg} / \mathrm{ml}(\mathrm{p}=0.626)$.

The results found for interleukin 12, in groups 1 and 2, were, respectively: $4.21 \pm 0.79 \mathrm{pg} / \mathrm{ml}$ and $2.88 \pm$ $1.60 \mathrm{pg} / \mathrm{ml}(\mathrm{p}=0.425)$ and $3.60 \pm 0.44 \mathrm{pg} / \mathrm{ml}$ and $3,67 \pm 0.49 \mathrm{pg} / \mathrm{ml}(\mathrm{p}=0.489)$ (Table 2).

Regarding TNF, we observed changes in the medians of their concentrations, remaining similar throughout the treatment; however, without statistical significance, in both groups $(4.54 \pm 1.099 \mathrm{pg} / \mathrm{ml}$ and $3.16 \pm 1.98 \mathrm{pg} / \mathrm{ml}(\mathrm{p}=1.00)$ and $3.86 \pm 0.48 \mathrm{pg} / \mathrm{ml}$ and $3.87 \pm 0.47 \mathrm{pg} / \mathrm{ml}(\mathrm{p}=0.155)$, groups 1 and 2 respectively (Table 2 ). 
VEGF had a decrease in its medians, and this variation was statistically significant in both groups. Group $1: 170.04 \pm 120.54 \mathrm{pg} / \mathrm{ml}$ and $0.0 \pm 57.23 \mathrm{pg} / \mathrm{ml}(\mathrm{p}=0.0039)$ and Group 2: $174.73 \pm 142.91 \mathrm{pg} / \mathrm{ml}$ and $0.00 \pm 0.00 \mathrm{pg} / \mathrm{ml}(\mathrm{p}=0.0019)$ (Figure 8).

The presence of b-FGF was only detected in only 3 patients in group 1 and none in group 2 . Thus, we could analyze its variations during the research (Table 2).

\section{Discussion}

The role of cytokines in the progression of diabetic retinopathy and the formation and maintenance of diabetic macular edema has long been studied.

Molecules such as interleukins, TNF, VEGF, b-FGF are important components that are involved in the pathophysiology of diabetic retinopathy and have become the object of study to determine the function of each one in this disease.

In this study, we produced an unprecedented analysis of variations in the levels of these cytokines during the treatment of diabetic macular edema, in patients with and without peripheral retinal ischemia, using an antiangiogenic drug called ranibizumab.

The purpose of selecting patients, with or without peripheral retinal ischemia, was to investigate how much the hypoxia condition can influence the expression of these cytokines and interfere with the result of the treatment of diabetic macular edema as well as to analyze their variations on the action of an antiVEGF drug.

Knowing the importance of the role of these cytokines, we chose to study their concentrations during the treatment of diabetic macular edema with a drug that has the function of stabilizing vascular permeability and acting by inhibiting one of these molecules.

According to studies, the intraocular levels of TNF and IL-1 must be elevated, when there is a state of edema because they have the power to induce an increase in vascular permeability with the breakdown of the internal hematoretinal barrier ${ }^{19,21,22}$.

In this study, when comparing the levels of IL-1 and TNF, before treatment, they were slightly higher than the control group. When doing a longitudinal analysis, we observed that the levels of IL-1 and TNF varied little, during the research, in both groups.

Interleukin 6 is considered a potent proinflammatory cytokine that plays an important role in the mechanisms of chronification of inflammatory processes ${ }^{25}$.

Chernykh and collaborators showed that patients with proliferative diabetic retinopathy have high levels of IL- 6 in the vitreous, being significantly higher than in patients without diabetes ${ }^{23}$. An important aspect 
of the research carried out by the Chernykh group was in the selected patients with RDP, that is, patients who have pictures of retinal ischemia.

In this study, the median values of IL-6, before treatment, were approximately 2.5 times higher in ischemic patients than the non-ischemic patients and 3.4 times higher than the control group at the beginning of treatment. Thus, we can think that this cytokine may have a great relationship with the state of retinal hypoxia.

VEGF is considered to be one of the main agents in the progression of retinal vascular diseases. They stimulate the inflammatory process, increase vascular permeability, and the appearance of new vessels ${ }^{26,27,28,29}$.

Osamu and collaborators studied the variation in VEGF concentrations in aqueous humor, before and after intravitreal injection of bevacizumab, in patients with proliferative diabetic retinopathy. The medications were performed one week before the patients were submitted to vitrectomy surgery through pars plana. The samples were collected before the injection and during the surgery. They concluded that there was a significant decrease in the concentration of vitreous VEGF, after one week of its administration ${ }^{30}$.

Another study also presented data on VEGF concentrations in patients with DR. The results suggested a significant relationship between VEGF levels and disease progression, showing its importance in the pathogenesis of diabetic retinopathy ${ }^{31}$.

VEGF was the molecule that showed the greatest variation in concentration levels, a decrease of approximately 5 times, in both groups (Figure 8).

Although we observed higher levels in patients with peripheral ischemia, the numbers were not statistically significant than those without peripheral retinal ischemia (Table 1).

The expression of b-FGF is related to the time of ischemia that tissue is exposed to. Normally, its production is increased when there is a prolonged period of ischemia. One of its functions is to stimulate cell proliferation and induce angiogenesis ${ }^{32}$.

A study published in 2015 analyzed the levels of VEGF and b-FGF in patients with proliferative diabetic retinopathy treated with bevacizumab. We studied 68 eyes, divided into 2 groups. Group 1: received bevacizumab before vitrectomy, 5 days before, and 14 days before surgery. Group 2: patients with a macular hole without retinopathy and previous treatment with bevacizumab. They concluded that patients with proliferative diabetic retinopathy had higher concentrations of VEGF than those without the disease. When analyzing the concentrations of b-FGF, the results showed that those who underwent surgery later had high levels of b-FGF than other groups ${ }^{33}$. 
In our study, b-FGF was only detected in only 3 patients in group 1 and none in group 2 . We did not find justifications for having been detected only in group 1. In group 2, the duration of ischemia or neovascular condition presented may not have been sufficient to induce the production of this cytokine (Table 1).

\section{Conclusion}

1. In patients with diabetic macular edema, without peripheral retinal ischemia, detected by wide-angle fluorescein angiography, treated with ranibizumab, there were statistically significant variations with an increase in their median levels in interleukin 6 and a decrease in VEGF levels. Interleukins 1, 8, 10, and 12, b-FGF, and TNF did not show statistically significant variations.

2. In patients with diabetic macular edema, with peripheral retinal ischemia, detected by wide-angle fluorescein angiography, treated with ranibizumab, we observed a statistically significant variation only in the VFGF levels. Interleukins 1, 68,10 , and 12, b-FGF, and TNF did not show statistically significant variations.

\section{Declarations}

Declarations: Not applicable

Funding: No funding existed for this study.

Conflicts of interest/Competing interests: The authors declare that they have no conflict of interest.

Ethical approval: approved by the Ethics Committee in the Medical Research Ethics Council of Hospital Agamenon Magalhães, Recife, Pernambuco (Number: 2.540.686).

Data availability: april 2018 to december 2018.

Informed consente: Informed consent was obtained from all individual participants included in the study.

\section{References}

1. Cheung N, Mitchell P, Wong TY. Diabetic retinopathy. Lancet. 2010;376(9735): 124-136.

2. Klein R; Klein BE; Moss SE. Visual impairment in diabetes. Ophthalmology. 91:1-9, 1984.

3. Nussenblatt RB; Kaufman SC; Palestine AG; Davis MD; Ferris FL 3rd. Macular thickening and visual acuity. Measurement in patients with cystoid macular edema. Ophthalmology. 94:1134-9, 1987.

4. Klein R. Diabetic retinopathy. Annu Rev Public Health. 17:137-58, 1996.

5. Romero-Aroca P.; Baget-Bernaldiz M.; Pareja-Rios A.; Lopez-Galvez M.; Navarro-Gil R.; Verges R. Diabetic Macular Edema Pathophysiology: Vasogenic versus Inflammatory. J Diabetes Res. 2156273, 2016. 
6. Rabiolo A.; Parravano M.; Querques L, et al. Ultra-wide-field fluorescein angiography in diabetic retinopathy: a narrative review. Clinical Ophthalmology.11:803-807, 2017.

7. Wessel MM.; Aaker GD.; Parlitsis G.; Cho M.; D'amico DJ, Kiss S. Ultra-wide-field angiography improves the detection and classification of diabetic retinopathy. Retina. 32(4):785-91, 2012.

8. Wessel MM, Nair N, Aaker GD, Ehrlich JR, D'amico DJ, KISS S. Peripheral retinal ischaemia, as evaluated by ultra-widefield fluorescein angiography, is associated with diabetic macular oedema. $\mathrm{Br}$ J Ophthalmol. 96(5):694-698, 2012.

9. Ghasemi FK.; WANG K.; KHADAMY J.; SADDA SR. Ultra-wide-field imaging in diabetic retinopathy; an overview. Journal of Current Ophthalmology. 28(2):57-60, 2016.

10. Silva PS.; Cavallerano JD.; Sun JK.; Soliman AZ.; Aiello LM.; Aiello LP. Peripheral lesions identified by mydriatic ultrawide field imaging: distribution and potential impact on diabetic retinopathy severity. Ophthalmology. 120(12):2587-95, 2013.

11. Silva PS.; Cavallerano JD.; Haddad NM.; Kwak H.; Dyer KH.; Omar AF.; Shikari H.; Aiello LM.; Sun JK.; Aiello LP. Peripheral Lesions Identified on Ultrawide Field Imaging Predict Increased Risk of Diabetic Retinopathy Progression over 4 Years. Ophthalmology. 122(5):949-56, 2015.

12. Price LD.; Au S.; Chong NV. Optomap ultrawide field imaging identifies additional retinal abnormalities in patients with diabetic retinopathy. Clinical Ophthalmology. 9:527-531, 2015.

13. Ghasemi FK.; Wang K.; Khadamy J.; Sadda SR. Ultra-wide-field imaging in diabetic retinopathy; an overview. Journal of Current Ophthalmology. 28(2):57-60, 2016.

14. Aiello LP.; Avery RL.; Arrigg PG.; Keyt BA.; Jampel HD.; Shah ST.; Pasquale LR.; Thieme H.; Iwamoto MA.; Park JE. et al. Vascular endothelial growth factor in ocular fluid of patients with diabetic retinopathy and other retinal disorders. N Engl J Med. 331(22):1480-7, 1994.

15. Adamis, A.P.; Miller, J.W.; Bernal, M.T.; D'amico, D.J.; Folkman, J.; Yeo, T.K.; Yeo, K.T. Increased vascular endothelial growth factor levels in the vitreous of eyes with proliferative diabetic retinopathy. Am J Ophthalmol. 118(4):445-450, 1994.

16. Romero-Aroca P.; Baget-Bernaldiz M.; Pareja-Rios A.; Lopez-Galvez M.; Navarro-Gil R.; Verges R. Diabetic Macular Edema Pathophysiology: Vasogenic versus Inflammatory. J Diabetes Res. 2156273, 2016.

17. Browning DJ, Stewart MW, Lee C. Diabetic macular edema: Evidence-based management. Indian J Ophthalmol. 66(12):1736-1750, 2018.

18. Zwahlen R.; Walz A.; Rot A. In vitro and in vivo activity and pathophysiology of human interleu-kin-8 and related peptides. Int Rev Exp Pathol. 34:27-42, 1993.

19. Joussen A.; Poulaki V.; Tsujikawa A, et al. Suppression of diabetic retinopathy with angiopoietin 1. Am J Pathol. 160:1683-93, 2002.

20. Murugeswari P.; Shukla D.; Rajendran A.; Kim R.; Namperumalsamy P.; Muthukkaruppan V. Proinflammatory cytokines and angiogenic and anti-angiogenic factors in vitreous of patients with proliferative diabetic retinopathy and eales' disease. Retina. 28(6):817-24, 2008. 
21. Joussen AM.; Doehmen S.; Le ML, et al. TNF-alpha mediated apoptosis plays na important role in the development of early diabetic retinopathy and long-term histopathological alterations. Mol Vis. 15:1418-1428, 2009.

22. Aveleira CA.; Lin CM.; Abcouwer SF, et al. TNF-a signals through PKCZ/NF-KB to alter the tight junction complex and increase retinal endothelial cell permeability. Diabetes. 59:2872-2882, 2010.

23. Chernykh VV.; Varvarinsky EV.; Smirnov EV.; Chernykh DV.; Trunov AN. Proliferative and inflammatory factors in the vitreous of patients with proliferative diabetic retinopathy. Indian $\mathrm{J}$ Ophthalmol. 63(1):33-6, 2015.

24. Zhou Y.; Yoshida S.; Kubo Y, et al. Interleukin-12 inhibits pathological neovascularization in rat model of oxygen-induced retinopathy. Sci Rep. 6:28140, 2016.

25. Neurath MF.; Finotto S. IL-6 signaling in autoimmunity, chronic inflammation and inflammationassociated cancer. Cytokine Growth Factor Rev. 22(2):83-9, 2011.

26. Frank RN.; Amin, RH.; Eliott, D.; Puklin, JE.; Abrams, GW. Basic fibroblast growth factor and vascular endothelial growth factor are present in epiretinal and choroidal neovascular membranes. American Journal Ophthalmology, v.122, n.3, p.393-403, Sept. 1996.

27. Kvanta A; Algvere, PV; Berglin, L; Seregard, S. Subfoveal fibrovascular membranes in age-related macular degeneration express vascular endothelial growth factor. Investing Ophthalmol Vis Science, v.37, n.9, p.1929-1934, 1996.

28. Otani A.; Takagi, H.; Oh, H.; Koyama, S.; Ogura, Y.; Matumura, M.; Honda, Y. Vascular endothelial growth factor family and receptor expression in human choroidal neovascular membranes. Microvascular Research, v.64, n.1, p.162-169, 2002.

29. Ameri H.; Chader, GJ.; Kim, JG.; Rao, NA.; Humayun, MS. The effects of intravitreous bevacizumab on retinal neovascular membrane and normal capillaries in rabbits. Investigative Ophthalmology \& Visual Science, v.48, n.12, p.5708-5715, 2007.

30. Sawada 0.; Kawamura H.; Kakinoki M.; Sawada T.; Ohji M. Vascular endotelial growth factor in aqueous humor before and after intravitreal injection of bevacizumab in eyes with diabetic retinopathy. Arch Ophthalmol. 125(10):1363-6, 2007.

31. Funatsu H.; Yamashita H.; Noma H, Mimura T.; Nakamura S.; Sakata K, Hori S. Aqueous humor levels of cytokines are related to vitreous levels and progression of diabetic retinopathy in diabetic patients. Graefes Arch Clin Exp Ophthalmol. 243(1):3-8, 2005.

32. Beranek M.; Kolar P.; Tschoplova S.; Kankova K.; Vasku A. Genetic variation and plasma level of the basic fibroblast growth factor in proliferative diabetic retinopathy. Diabetes Res Clin Pract. 79(2):3627, 2008.

33. Li A.; Dubey S.; Varney ML.; Dave BJ.; Singh RK. IL-8 directly enhanced endothelial cell survival, proliferation, and matrix metalloproteinases production and regulated angiogenesis. J Immunol. 170(6):3369-76, 2003.

\section{Tables}


Table 1: Values of medians and standard deviation of cytokines in aqueous humor in the initial time of treatment (D1) and after treatment (D3), for the groups: non-ischemic and ischemic and values of the medians of the control group at baseline treatment. D1: First collection; D3: Third Collection.

Table 2: Variation of medians and standard deviation of cytokines in aqueous humor in the initial time of treatment (D1) and after treatment (D3) for groups 1 and 2.

\begin{tabular}{|c|c|c|c|c|c|c|}
\hline & Grupo sem Isquemia & & & Grupo com Isquemia & & \\
\hline & Variaçăo das medianas & Desvio padrăo & P. & Variaçăo das medianas & Desvio padrăo & P. \\
\hline IL - 1 & $1,61-0,00$ & $(+/-) 1,66 / 2,53$ & 0,4185 & $0,81-0,56$ & $(+/-) 0,85 / 0,92$ & 0,441 \\
\hline IL - - & $10,78-26,35$ & $(+/-) 4,09 / 19,56$ & 0,0148 & $28,02-27,41$ & $(+/-) 20,3 / 211,62$ & 0,194 \\
\hline IL - - & $13,8-18,15$ & $(+/-) 3,95 / 12,65$ & 0,0234 & $15,43-20,8$ & $(+/-) 10,65 / 19,73$ & 0,037 \\
\hline IL - 10 & $5,62-5,29$ & $(+/-) 0,70 / 1,17$ & 1,000 & $5,71-5,76$ & $(+/-) 0,40 / 0,29$ & 0,626 \\
\hline IL - 12 & $4,21-2,88$ & $(+/-) 0,79 / 1,60$ & 0,425 & $3,60-3,67$ & $(+/-) 0,44 / 0,49$ & 0,489 \\
\hline TNF & $4,54-3,16$ & $(+/-) 1,09 / 1,98$ & 1,00 & $3,86-3,87$ & $(+/-) 0,48 / 0,47$ & 0,155 \\
\hline VEGF & $170,04 .-0,0$ & $(+/-) 120,54 / 57,23$ & 0,003 & $174,73-0,0$ & $(+/-) 0,00 / 0,00$ & 0,002 \\
\hline BFGF & 0 & 0 & 0 & 0 & 0 & 0 \\
\hline
\end{tabular}

Figures 


\begin{tabular}{|c|c|c|c|c|c|}
\hline Cytokine & Groups & $\begin{array}{l}\text { Median in } \\
\text { D1 }\end{array}$ & $\begin{array}{l}\text { Standard } \\
\text { deviation }\end{array}$ & $\begin{array}{l}\text { Median in } \\
\text { D3 }\end{array}$ & $\begin{array}{l}\text { Standard } \\
\text { deviation }\end{array}$ \\
\hline \multirow[t]{3}{*}{ IL12 } & 1 - Control & 3,4 & 0,18 & & \\
\hline & $\begin{array}{l}2 \text { - Without } \\
\text { Ischemia }\end{array}$ & 4,21 & 0,79 & 2,88 & 1,60 \\
\hline & 3 - ischemia & 3,6 & 0,44 & 3,67 & 0,46 \\
\hline \multirow[t]{3}{*}{ IL06 } & 1 - Control & 8,23 & 3,33 & & \\
\hline & $\begin{array}{l}2 \text { - Without } \\
\text { Ischemia }\end{array}$ & 10,78 & 4,09 & 26,35 & 19,56 \\
\hline & 3 - ischemia & 28,02 & 20,31 & 27,41 & 211,62 \\
\hline \multirow[t]{3}{*}{ IL08 } & 1 - Control & 4,66 & 3,21 & & \\
\hline & $\begin{array}{l}2 \text { - Without } \\
\text { Ischemia }\end{array}$ & 13,18 & 3,95 & 18,15 & 11,94 \\
\hline & 3 - ischemia & 15,43 & 10,65 & 20,80 & 19,73 \\
\hline \multirow[t]{3}{*}{ IL10 } & 1 - Control & 5,77 & 0,31 & & \\
\hline & $\begin{array}{l}2 \text { - Without } \\
\text { Ischemia }\end{array}$ & 5,62 & 3,95 & 18,15 & 11,94 \\
\hline & 3 - ischemia & 5,71 & 10,65 & 20,80 & 19,73 \\
\hline \multirow[t]{3}{*}{ IL1-1 } & 1 - Control & 0 & 25,52 & & \\
\hline & $\begin{array}{l}2 \text { - Without } \\
\text { Ischemia }\end{array}$ & 1,61 & 1,55 & 0,00 & 2,53 \\
\hline & 3 - ischemia & 0,81 & 0,85 & 0,56 & 0,92 \\
\hline \multirow[t]{3}{*}{ TNF } & 1 - Control & 3,8 & 0,21 & & \\
\hline & $\begin{array}{l}2 \text { - Without } \\
\text { Ischemia }\end{array}$ & 4,54 & 1,09 & 3,16 & 1,98 \\
\hline & 3 - ischemia & 3,86 & 0,48 & 3,87 & 0,47 \\
\hline \multirow[t]{3}{*}{ VEGF } & 1 - Control & 132,54 & 99,94 & & \\
\hline & $\begin{array}{l}2 \text { - Without } \\
\text { Ischemia }\end{array}$ & 170,04 & 120,54 & 0,00 & 57,23 \\
\hline & 3 - ischemia & 174,73 & 142,91 & 0,00 & 0,00 \\
\hline \multirow[t]{3}{*}{ bFGF } & 1 - Control & 0 & 0 & & \\
\hline & $\begin{array}{l}2 \text { - Without } \\
\text { Ischemia }\end{array}$ & 0 & 10,53 & 0,00 & 0,00 \\
\hline & 3 - ischemia & 0 & 0 & 0,00 & 0,00 \\
\hline
\end{tabular}




\section{BEFORE EACH INJECTION:}

OPHTHALMIC CLINICAL EXAM

RETINOGRAPHY + WIDE-FIELD FLUORESCEIN ANGIOGRAPHY + OCT

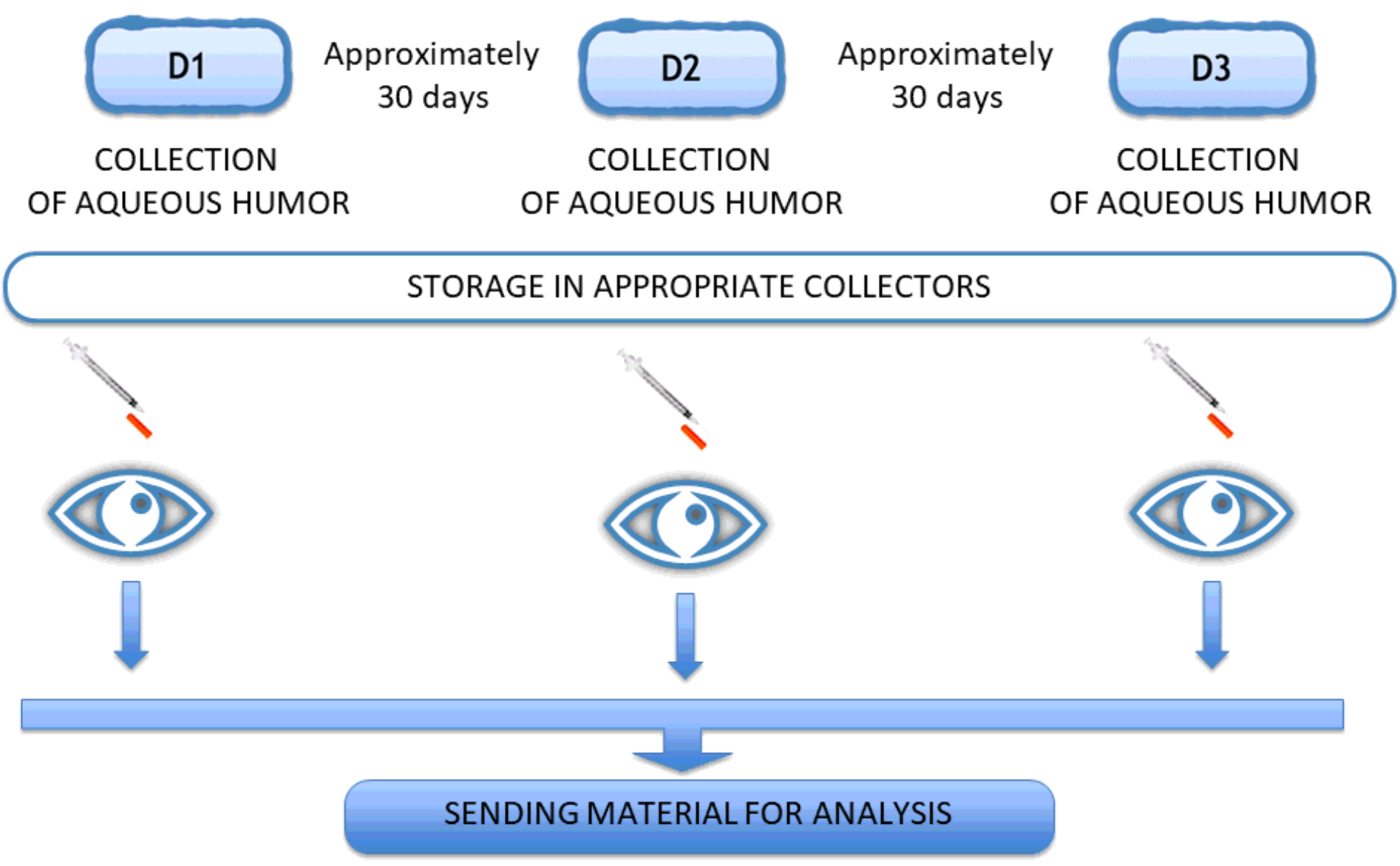

Figure 1

Study design. 
Graph 1: Comparison of the variation in visual acuity in the non-ischemic and ischemic groups.
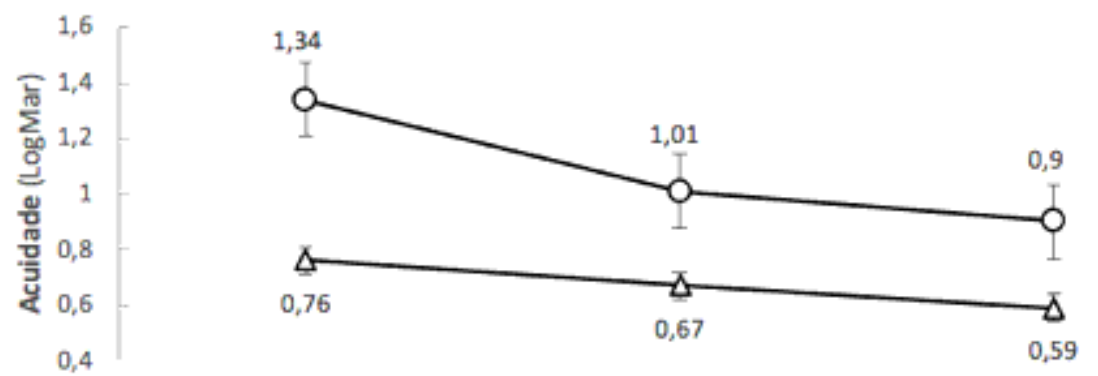

$1^{*}$ Coleta $2^{*}$ Coleta $\quad 3^{*}$ Coleta

$-\infty$ ischemic $-\sim-$ non-ischemic

\section{Figure 2}

Comparison of the variation in visual acuity in the non-ischemic and ischemic groups.
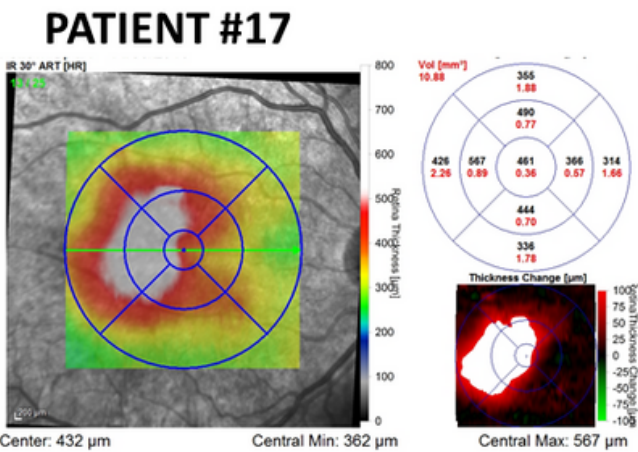

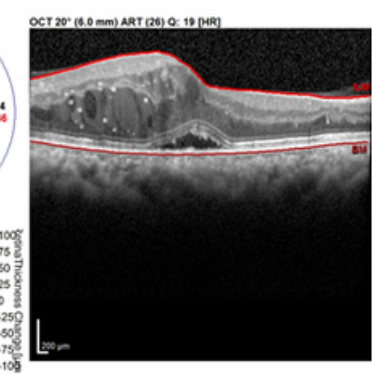

Circle Diameters: $1,3,6 \mathrm{~mm}$ ETDRS

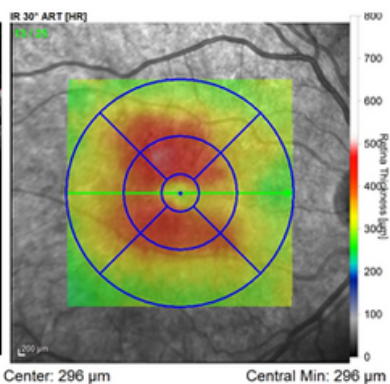

Central Min: $296 \mu \mathrm{m}$

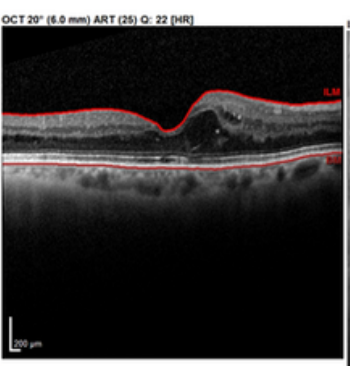

Circle Diameters: $1,3,6$ mm ETDRS

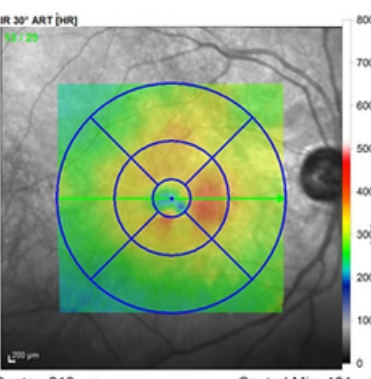

Central Min: 191 u

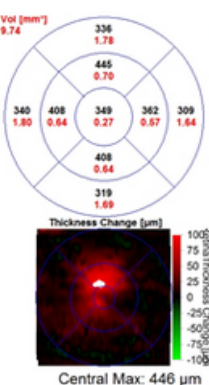

Central Max: $446 \mu \mathrm{m}$

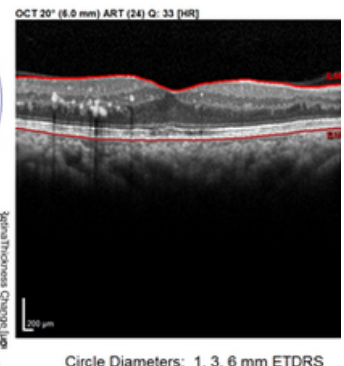

Circle Diameters: $1,3,6 \mathrm{~mm}$ ETDRS

\section{PATIENT \#20}
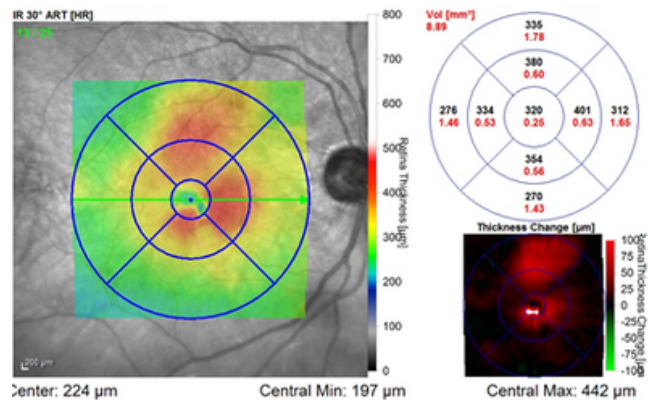

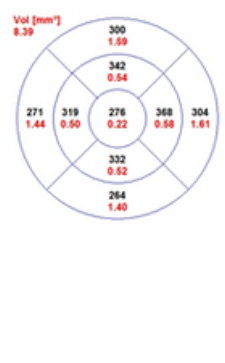

Central Max: $383 \mu \mathrm{m}$

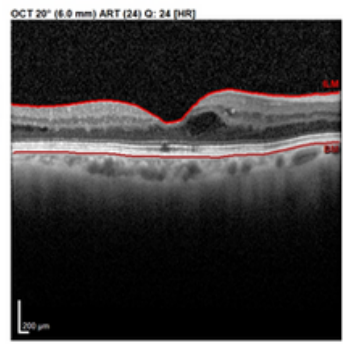

Circle Diameters: 1, 3, 6 mm ETDRS 


\section{PATIENT \#10}

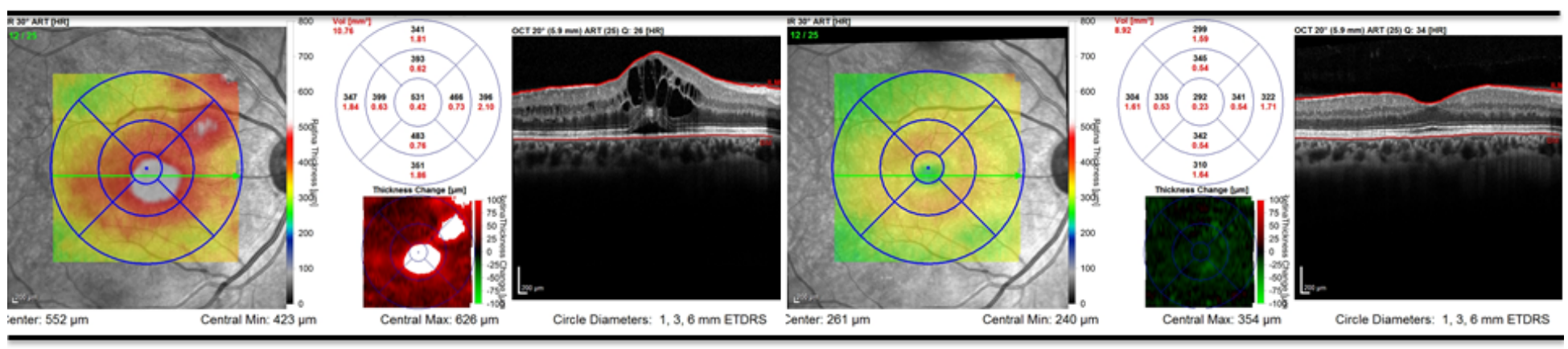

\section{PATIENT \#6}
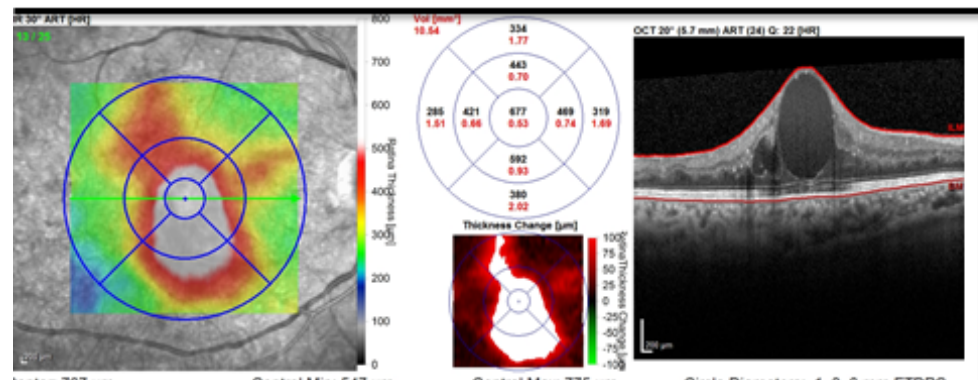

Circle Diameters: 1, 3, 6 mm ETDRS
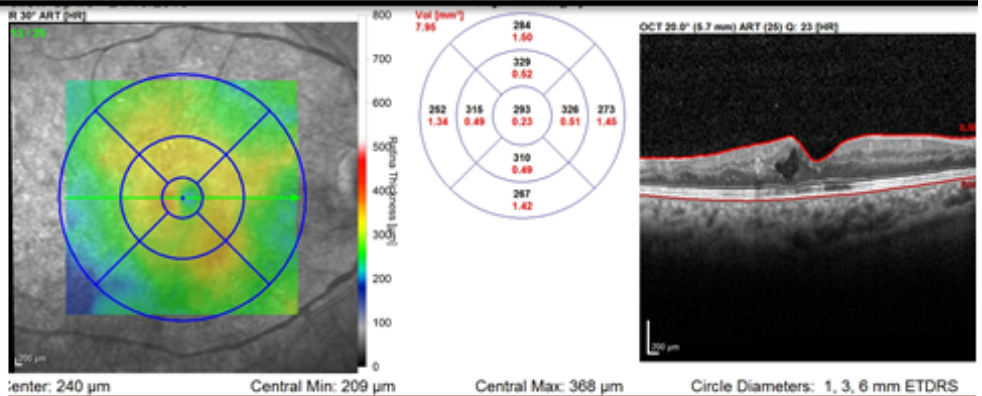

Circle Diameters: 1, 3,6 mm ETDRS

Figure 4

Upon OCT examination, all patients presented a reduction in central macular thickness upon analysis of the macular thickness map, as illustrated in two patients (Figure 4). 

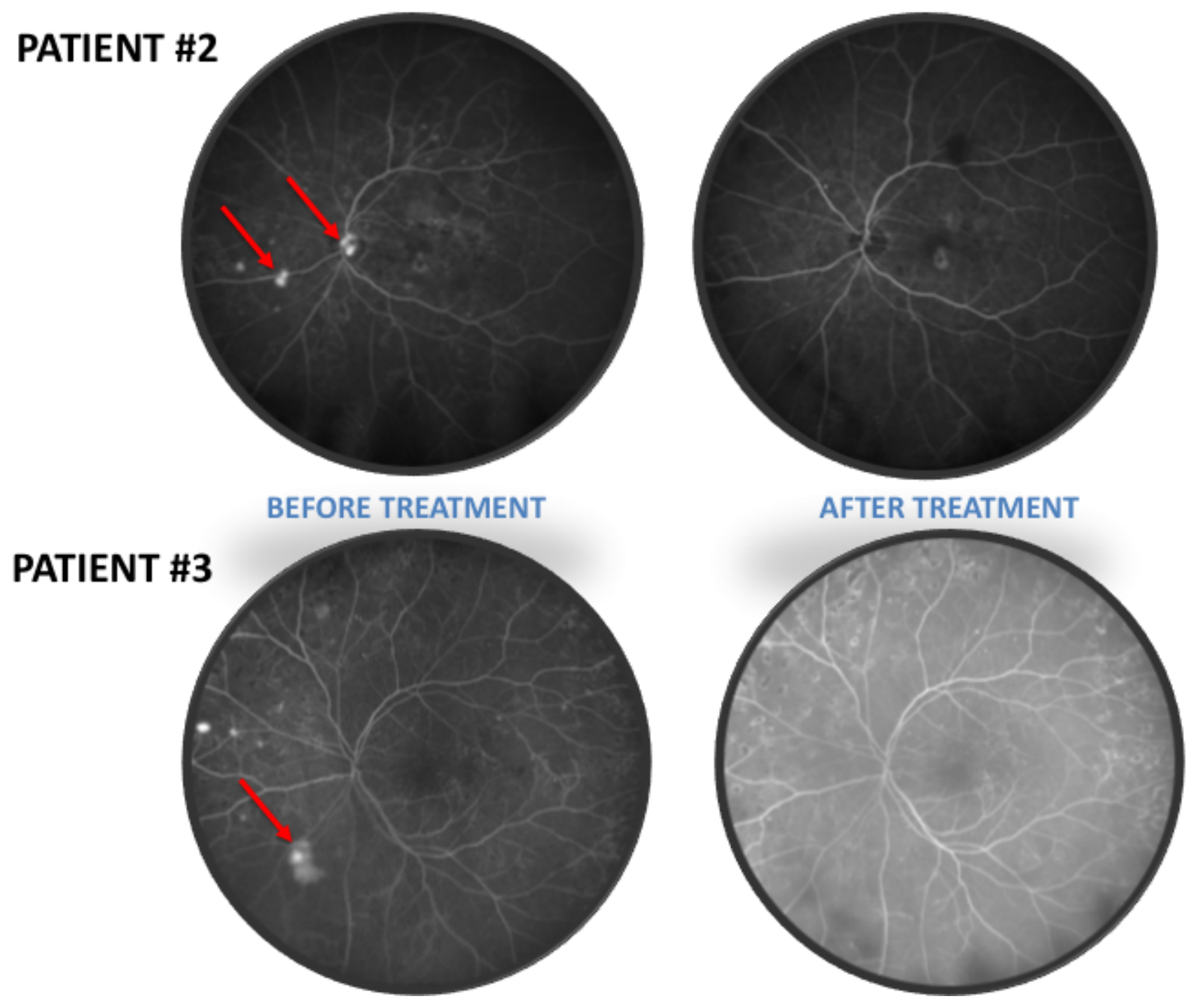

\section{Figure 5}

At the beginning of the study, on angiography, two patients had retinal neovessels and one of them also had disc neovessels at the beginning of treatment. At the end of the study, both patients presented regression of the new vessels (Figure 5). 
Graph 2: Variation of medians of IL-6 during treatment in groups 1 and 2.

D1: First collection; D2: Second Collection; D3: Third Collection.
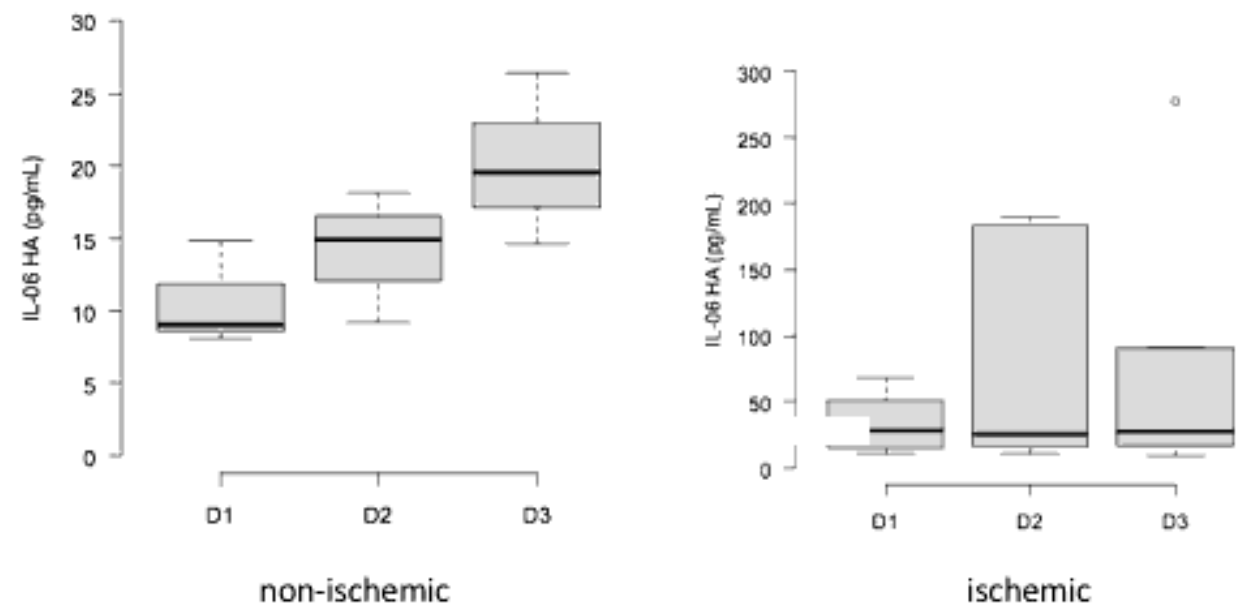

\section{Figure 6}

Variation of medians of IL-6 during treatment in groups 1 and 2. D1: First collection; D2: Second Collection; D3: Third Collection.

Graph 3: Variation of IL-8 medians during treatment in groups 1 and 2.

D1: First collection; D2: Second Collection; D3: Third Collection.

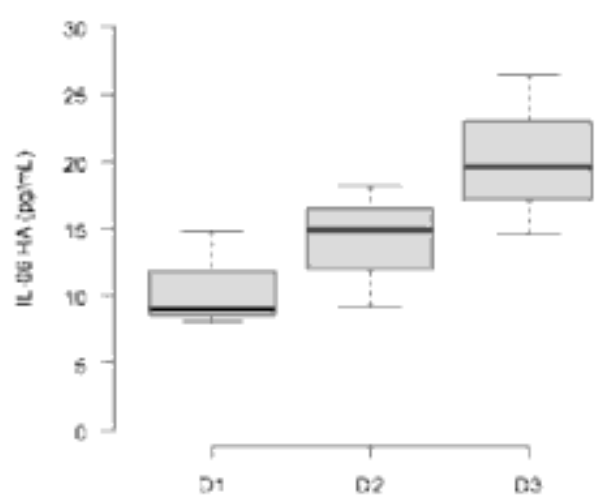

non-ischemic

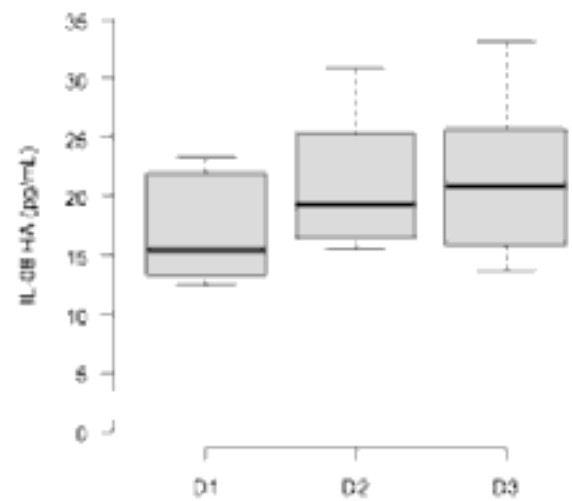

ischemic 
Variation of IL-8 medians during treatment in groups 1 and 2. D1: First collection; D2: Second Collection; D3: Third Collection.

Graph 4: Variation of medians of VEGF before and after treatment in groups 1 and 2. D1: First collection; D3: Third Collection.
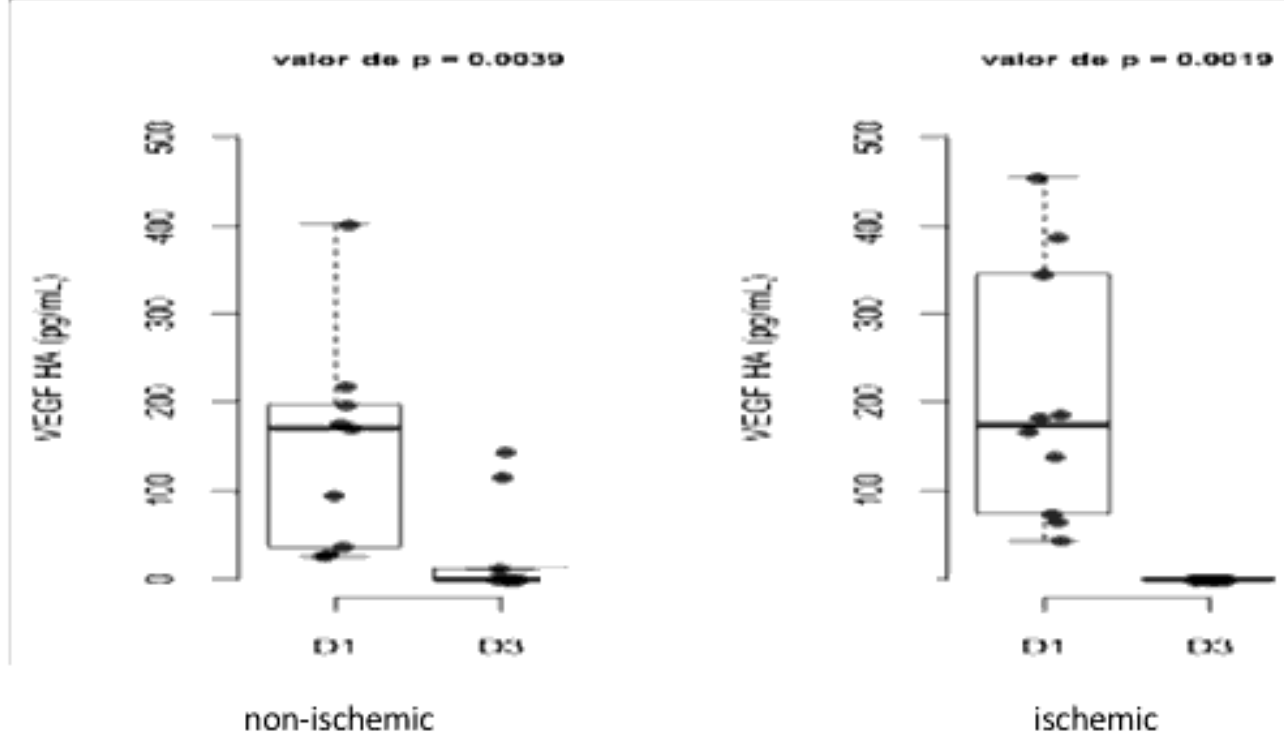

Figure 8

Variation of medians of VEGF before and after treatment in groups 1 and 2. D1: First collection; D3: Third Collection. 